\title{
MELTING CURVE ANALYSIS FOR THE SCREENING OF HEPATITIS B VIRUS GENOTYPES A, D AND F IN PATIENTS FROM A GENERAL HOSPITAL IN SOUTHERN BRAZIL
}

\author{
Carlos Eduardo BECKER ${ }^{1}$, Nelson Alexandre KRETZMANN ${ }^{1}$, Ângelo Alves de MATTOS ${ }^{1}$ and \\ Ana Beatriz Gorini da VEIGA', 2
}

\begin{abstract}
Context - Hepatitis B virus (HBV) can cause fulminant hepatitis, cirrhosis and hepatocellular carcinoma, and is one of the most common causes of acute and chronic liver failure. The genetic variants of HBV can be decisive for the evolution of these diseases as well as for the election of therapy. Objectives - The aim of this study was to evaluate and standardize an in house methodology based on the analysis of the melting curve polymerase chain reaction (PCR) of real-time (qPCR) to screen for genotypes A, D and F of HBV in patients from a hospital in Rio Grande do Sul, Brazil. Methods - We evaluated 104 patients presumably with HBV chronic infection. Viral DNA was extracted from plasma and viral genotypes and different mutations were determined using PCR-based protocols. Results - A PCR-based methodology was standardized for the analysis of genotypes A, D and F of HBV. The technique was based in a nested PCR with the final step consisting of a multiplex real-time PCR, using the melting curve as a tool for the differentiation of fragments. A higher frequency of genotype D (44.4\%), followed by genotype A $(22.2 \%)$ and genotype F (3.7\%) was observed. Conclusion - The standardized assay, a nested PCR-multiplex qPCR using specific primers, provides a rapid and accurate method for the differentiation of HBV genotypes that are more frequent in Southern Brazil - A, D and F. This method can be applied in the clinical practice.
\end{abstract}

HEADINGS - Hepatitis B virus. Melting Curve Analysis. Genotype. Real-time polymerase chain reaction. Minas Gerais, Brazil.

\section{INTRODUCTION}

Infection by hepatitis B virus (HBV) is a serious global public health problem ${ }^{(6)}$. The infection can be transmitted through sexual intercourse, parenteral contact or vertical transmission (mother-to-child), and can lead to chronic liver disease, including cirrhosis and hepatocellular carcinoma (HCC) ${ }^{(10)}$.

In Brazil, the Ministry of Health estimates that at least $15 \%$ of the population has already been infected with HBV, with chronic disease in about $1 \%$ of the Brazilian population and a mortality rate of 0.6 per 100,000 inhabitants $^{(9)}$. The medical literature refers to the southern region as an area of low endemicity; the Midwest, Northeast and Southeast regions as intermediate endemicity; and the Amazon region, the State of Espírito Santo and the Western region of the State of Santa Catarina as regions of high endemicity ${ }^{(2,4,9,29)}$.

The molecular characteristics of the virus are responsible for the development not only of acute hepatitis $\mathrm{B}$, but also for various manifestations of chronic liver disease, accounting for an important percentage of liver diseases ${ }^{(1)}$.

The progression of liver disease, as well as the response to antiviral therapy, are dependent on the HBV genotype ${ }^{(16)}$. The course of HBV infection is influenced by many factors that affect the virus-host interaction, including genetic factor such as the viral genotype, which can influence the expression of the viral antigens ${ }^{(26)}$. Eight different HBV genotypes (A-H), with distinct geographic distribution, are known ${ }^{(15)}$.

The investigation of the distribution of viral genomes may reveal variations between genotypes, which might be associated, for instance, with bad prognosis or even with more effective treatment options. Molecular diagnostic tests analyze the genetic content for information of the virus. These tests allow the analysis of sequences of specific regions of the viral genetic material, to identify mutations or quantify the levels of genetic material that can be expressed ${ }^{(21)}$.

Universidade Federal de Ciências da Saúde de Porto Alegre - Programa de Pós-Graduação em Medicina: Hepatologia: ${ }^{2}$ Universidade Federal de Ciências da Saúde de Porto Alegre - Programa de Pós-Graduação em Patologia.

Correspondence: Ana Beatriz Gorini da Veiga. Universidade Federal de Ciências da Saúde de Porto Alegre - Biologia Molecular. Programa de Pós-Graduação em Hepatologia. Rua Sarmento Leite, 245 -90050-170. Porto Alegre, RS, Brasil. E-mail:anabgv@ufcspa.edu.br 
Viral load data obtained by quantitative real time polymerase chain reaction (qPCR) prior to treatment can be used in the evaluation of prognosis in response to treatment. HBV genotyping is generally carried out by DNA sequencing ${ }^{(2)}$.

In view of the severity of liver disease in HBV patients, and the viral genetic characteristics as determinants of liver disease progression, the present study aimed to develop a practical, rapid and low cost methodology for the screening of HBV genotypes A, D and F in patients of Rio Grande do Sul, through the use of the melting curve analysis of qPCR products.

\section{METHODS}

The study included 104 patients with chronic infection by hepatitis B virus attended to in the Gastroenterology Center and Liver Transplant Unit of the Complexo Hospitalar Irmandade Santa Casa de Misericórdia in Porto Alegre, Rio Grande do Sul, Brazil.

The inclusion criteria were: patients with requested search for HBsAg in serum, independent of serum levels of ALT and AST. The exclusion criteria were: patients with positive anti-HCV or anti-HIV serum, presence of co-infection with the delta virus (HDV), daily alcohol intake higher than $40 \mathrm{~g}$, and use of potentially hepatotoxic drugs.

A pre-established form was filled at the Gastroenterology Center or Liver Transplant. The results of the following laboratory tests were registered: ALT and AST, total anti-HBc, anti-HBs, anti-HBe and $\mathrm{HBeAg}$. This study was approved by the Research Ethics Committee of Universidade Federal de Ciências da Saúde de Porto Alegre (UFCSPA), and registered at the National Ethics Research Committee (CONEP) under number 09-443.

\section{Determination of genotypes and viral mutations}

The HBV genotypes were determined by sequencing and qPCR reaction; the mutations were determined by sequencing, according to Sitnik et al. ${ }^{(32)}$.

\section{Polymerase chain reaction (PCR)}

The viral DNA was extracted with PureLink ${ }^{\mathrm{TM}}$ Viral RNA/DNA Mini kit (Invitrogen, CA), according to the manufacturer's instructions.

The DNA was first amplified by nested PCR with two pairs of specific primers (Table 1) for each reaction (sequencing reaction for all samples and screening by qPCR with discrimination of genotypes by melting curve analysis).

\section{Nested PCR for sequencing and for qPCR}

Sera of patients underwent two rounds of amplification using external (FHBS1 and RHBS1) and internal primers (FHBS2 and RHBS2) for the sequencing reaction. The HotStart mix (Promega, Brazil) was used for each PCR reaction, with a final primer concentration of $0.5 \mu \mathrm{M}^{(1)}$. The PCR was performed with the following cycles: initial denaturation at $94^{\circ} \mathrm{C}$ for $20 \mathrm{~s} ; 30$ cycles of $20 \mathrm{~s}$ at $94^{\circ} \mathrm{C}$, annealing at $56^{\circ} \mathrm{C}$ for $20 \mathrm{~s}$, extension at $72^{\circ} \mathrm{C}$ for $30 \mathrm{~s}$; and final extension at $72^{\circ} \mathrm{C}$ for $1 \mathrm{~min}$. All reactions were performed including negative and positive standards.

A nested triplex PCR reaction was performed for the melting curve analysis, according to Naito et al.(22), with modifications. The first step of the reaction was performed by conventional PCR (external primers), and the second step of the reaction was performed in a qPCR system (Applied Biosystem 7500), using the GoTaq ${ }^{\circledR}$ qPCR Master Mix kit (Promega, Brazil).

The FGEN and RGEN primers (final concentration $0.5 \mu \mathrm{M}$ each) were used for the first step of amplification, with the following conditions: initial denaturation at $94^{\circ} \mathrm{C}$ for 20 s; 50 cycles at $94^{\circ} \mathrm{C}$ for $20 \mathrm{~s}, 56^{\circ} \mathrm{C}$ for $30 \mathrm{~s}$ and $72^{\circ} \mathrm{C}$ for $30 \mathrm{~s}$; final extension at $72^{\circ} \mathrm{C}$ for $1 \mathrm{~min}$. The second PCR step used the FMA, RMA, FMD, FMF and RMD/F primers, all in the final concentration of $0.1 \mu \mathrm{M}$. The reaction conditions were: initial denaturation at $95^{\circ} \mathrm{C}$ for $50 \mathrm{~s} ; 20$ cycles of $94^{\circ} \mathrm{C}$ for $15 \mathrm{~s}, 58^{\circ} \mathrm{C}$ for $20 \mathrm{~s}, 72^{\circ} \mathrm{C}$ for $30 \mathrm{~s}$; final extension at $72^{\circ} \mathrm{C}$ for $1 \mathrm{~min}$. All reactions were performed with negative and positive standards.

TABLE 1. Description of primers

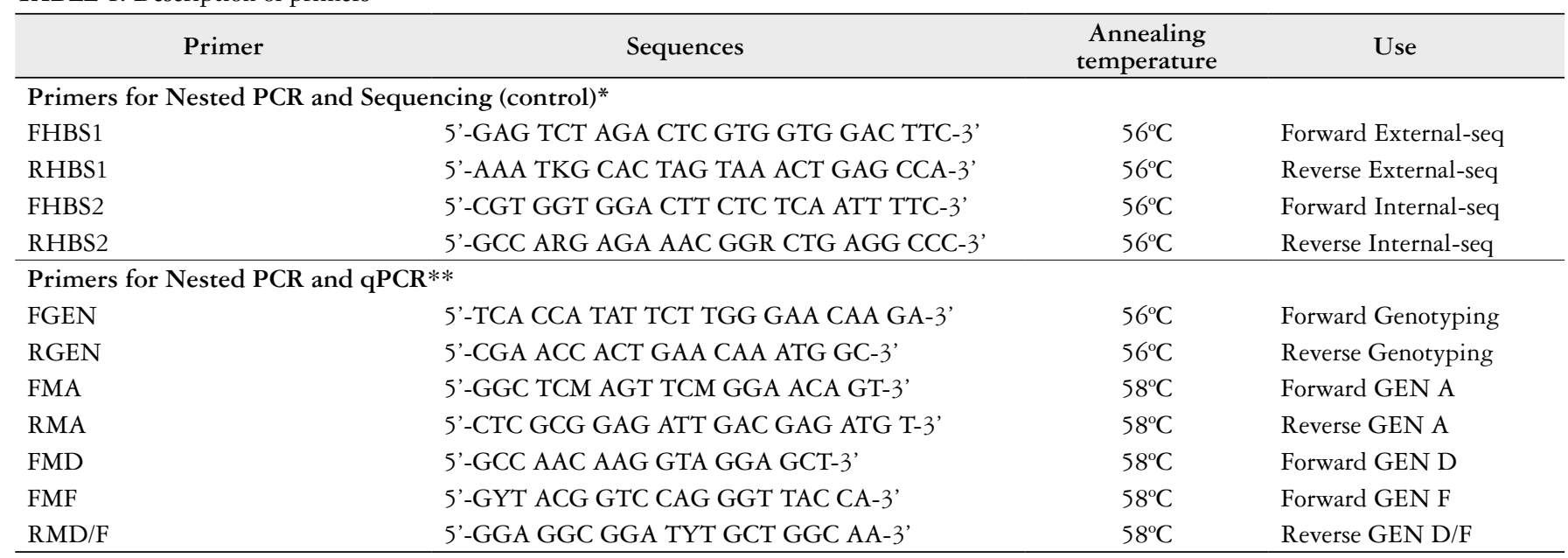

PCR: polymerase chain reaction; qPCR: real-time polymerase chain reaction; * Sitnik et al.(32); ** Naito et al.(22) 
The sensitivity of the lower limit of viral detection was established at 400 copies $/ \mathrm{mL}$.

\section{Sequencing Reaction}

The amplified fragments were sequenced based on the methodology described by Sanger et al ${ }^{(30)}$, using dideoxinucleotides (ddNTPs) labeled with fluorescent markers (Kit ABI PrismR BigDye ${ }^{\mathrm{TM}}$ Terminator Cycle Sequencing Ready Reaction, Applied Biosystems, Foster City, CA, USA). The automatic ABI 3130 DNA analyzer (Applied Biosystems) was used in a commercial molecular laboratory as control. All sequences were analyzed with the Chromas program (Version 2.31, Technelysium Pty Ltd) and translated with the DNA program for Windows (Version 2.2, David Dixon). The GeneMapper program Version 3.7 (Applied Biosystems) was used for comparison of the sequences obtained for all samples with known sequences of all HBV genotypes, to identify the viral genotype and subtype.

\section{Statistical Analysis}

The results were analyzed using descriptive statistical methods (mean, median, frequency and standard deviation), with the software SPSS version 18. Results were arranged in tables and charts, for best visualization.

\section{RESULTS}

This study was conducted with $104 \mathrm{HBV}$ patients, attended at the Complexo Hospitalar Santa de Misericórdia de Porto Alegre. A nested PCR method with a final step consisting of a multiplex real time PCR (Nested-Multiplex qPCR), using melting curve analysis for the identification of genotype-specific fragments, was standardized for analysis of HBV genotypes.

The average age of patients was 47.9 years, and males accounted for $70.3 \%$ of the sample (Table 2). Median values of liver transaminases were $34.5 \mathrm{U} / \mathrm{L}$ (ALT) and $32.0 \mathrm{U} / \mathrm{L}$ (AST), considered within the normal range (ALT, $50 \mathrm{U} / \mathrm{L}$ and AST, $40 \mathrm{U} / \mathrm{L}$ ). The serological analysis showed that $82.6 \%$ of the blood samples were positive for $\mathrm{HBsAg}, 20.5 \%$ for anti-HBsAg, $29.7 \%$ for $\mathrm{HBeAg}, 66.2 \%$ for anti-HBeAg, and 95,3\% for HBC-Total.

After extraction of DNA, samples were amplified by PCR and the fragments were analyzed by agarose gel electrophoresis, with detection of HBV. After confirmation of the presence of the fragment, each amplification product was used for the second amplification reaction with genotype-specific primers.

The second reaction, performed using the reagent Sybr Green, allows evaluation of the specificity of the reaction by melting curve analysis, with a specific melting temperature (Tm) for each fragment amplified. As already mentioned, the melting curve analysis is based on the Tm, in which half of the DNA molecules are in the form of single strand and the other half in the form of a double helix. The Tm is dependent on DNA composition, and is directly related to the $\mathrm{G}+\mathrm{C}$ content in DNA - which, in turn, involves a higher
TABLE 2. Clinical characteristics of patients and HBV genotypes

\begin{tabular}{ll}
\hline Variable & Values $\mathbf{n}(\%)$ \\
\hline $\begin{array}{l}\text { Age in years (mean-standard deviation) } \\
\text { Gender } \mathrm{n}(\%)\end{array}$ & $47.9 \pm 13.1$ \\
$\quad$ Male & $73(70.3 \%)$ \\
Female & $31(29.7 \%)$ \\
ALT median $(P 25-P 50)$ & $34.5(22.2-52.75)$ \\
AST & $32.0(23.0-57.0)$ \\
HBsAg $(\mathrm{n}=104)$ & \\
Positive & $86(82.6 \%)$ \\
Negative & $18(17.4 \%)$ \\
Anti-HBsAg $(\mathrm{n}=73)$ & \\
Positive & $15(20.5 \%)$ \\
Negative & $58(79.5 \%)$ \\
HBeAg $(\mathrm{n}=74)$ & \\
Positive & $22(29,7 \%)$ \\
Negative & $52(70,3 \%)$ \\
Anti-HBeAg $(\mathrm{n}=71)$ & \\
Positive & $47(66,2 \%)$ \\
Negative & $24(33,8 \%)$ \\
HBC-Total $(\mathrm{n}=64)$ & \\
Positive & $61(95,3 \%)$ \\
Negative & $3(4,7 \%)$ \\
Genotypes $(\mathrm{n}=104)$ & \\
A & $23(22,2 \%)$ \\
D & $46(44,4 \%)$ \\
F & $4(3,7 \%)$ \\
Undetectable & $31(29,6 \%)$ \\
\hline
\end{tabular}

number of $\mathrm{H}$ bonds. Since each amplified fragment has a specific size and base composition, they can be identified by melting curve analysis. In the present study, this analysis was also used for identification of HBV genotypes: A (68 bp), D (119 bp) and F (97 bp).

The technique used, Nested-Multiplex qPCR, allowed the identification of fragments with the expected melting temperature for each of the specific viral genotypes $(P<0.001)$ (Figure 1). The genotypes were confirmed by DNA sequencing (data not shown).

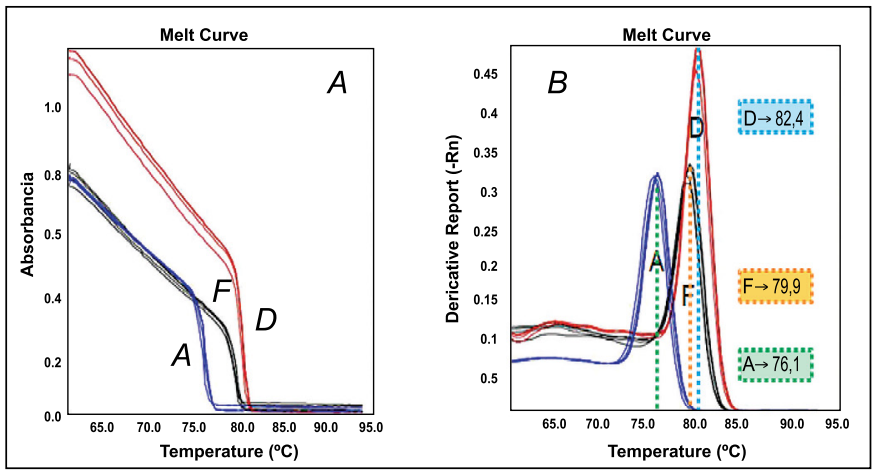

FIGURE 1. Melting curve analysis for HBV genotyping. (A) Normalized melting curves. (B) Derived melting curves. Genotypes A, D and F. 
The results showed a higher frequency of genotype D $(44.4 \%)$, followed by genotype A $(22.2 \%)$ and genotype F $(3.7 \%)$. It should be noted that, in $29.6 \%$ of the samples, $\mathrm{HBV}$ was undetectable (negative) by PCR. Considering the remaining samples, the frequency of the genotypes $\mathrm{A}, \mathrm{D}$ and F was $32 \%, 63 \%$ and $5 \%$, respectively.

Table 3 describes the molecular characteristics of patients according to HBV genotypes, as well as other clinical data.

Finally, DNA sequencing performed to confirm the genotypes found by qPCR reaction allowed also the analysis of mutations presented by HBV, as well as the associated resistance to the treatments available (data not shown). Only two mutations, unrelated with resistance to conventional treatment of patients with HBV, were observed in the 104 samples studied and genotyped.

\section{DISCUSSION}

Genotyping of HBV is important to investigate the route of infection and pathogenicity of the virus. In particular, the analysis of the DNA sequence in different viral isolates may identify their patterns of serological reactivity, pathogenicity, virulence and response to treatment. In addition, genetic variations of $\mathrm{HBV}$ have specific geographical distribution ${ }^{(2)}$.

In Brazil, yet there are few investigations on the prevalence of HBV genotypes and subtypes ${ }^{(2,4,9,34)}$. Some of the reasons for that are related to the short supply of commercial kits for genotyping and subtyping of $\mathrm{HBV}$, which causes the PCR techniques to be conducted in house, and the high cost of equipment and reagents necessary for molecular biology techniques, which greatly increase the difficulty in conducting studies in this line of research. However, the use of real-time PCR with Sybr Green can dramatically reduce these costs ${ }^{(24)}$.

In clinical practice, the molecular diagnosis of HBV usually includes serological analyses ${ }^{(6,7,14)}$. Two of the several types of molecular tests available for HBV diagnosis were used in this work: sequencing and PCR. The PCR for HBV is one of the most used methods, with complete or partial genome sequencing as a clinical tool for the determination of HBV genotypes. The costs of reagents and labor, however, are high $^{(2,5,8)}$. In research activities, sequencing is used for analysis of mutations in the genome of HBV.

Molecular and serological tests differ in their sensitivity and specificity to detect the different HBV diagnostic targets, as well as in their commercial availability, time between receiving the samples and producing the result, approval status by the authorities and in their ability to distinguish between viral genotypes ${ }^{(19,20)}$. In this context, the molecular techniques used to investigate $\mathrm{HBV}$ infection enable the detection of viral genetic material and are considered more adequate for diagnosis. On the other hand, rapid serologic tests generally detect viral antigens (proteins) and have low sensitivity for identification of polymorphisms and even pre-core mutations ${ }^{(3,32)}$.

TABLE 3. Clinical and Molecular Characteristics of Patients According to HBV Genotypes

\begin{tabular}{|c|c|c|c|}
\hline \multirow{2}{*}{ Variable } & \multicolumn{3}{|c|}{ Genotype } \\
\hline & A & $\mathrm{D}$ & $\mathrm{F}$ \\
\hline Age in years (mean-standard deviation) & $48.7 \pm 16.7$ & $45.69 \pm 12.4$ & $35.3+2.5$ \\
\hline $\begin{array}{l}\text { Gender n (\%) } \\
\text { Male } \\
\text { Female }\end{array}$ & $\begin{array}{c}15(66.7 \%) \\
8(33.3 \%)\end{array}$ & $\begin{array}{c}14(25 \%) \\
32(29.7 \%)\end{array}$ & $\begin{array}{c}4(100 \%) \\
-\end{array}$ \\
\hline ALT median $(P 25-P 50)$ & $30(14-43.5)$ & $42(23.7-71.7)$ & $49(33-52)$ \\
\hline AST & $34(26.7-42.2)$ & $36.5(22.2-59.7)$ & $39(28-60)$ \\
\hline AST & & & \\
\hline $\begin{array}{l}\text { Normal } \\
\text { High }\end{array}$ & $\begin{array}{c}13(76.5 \%) \\
4(23.5 \%)\end{array}$ & $\begin{array}{l}17(53.1 \%) \\
15(46.9 \%)\end{array}$ & $\begin{array}{l}2(66.7 \%) \\
1(33.3 \%)\end{array}$ \\
\hline ALT & & & \\
\hline $\begin{array}{l}\text { Normal } \\
\text { High }\end{array}$ & $\begin{array}{c}12(85.47 \%) \\
2(13.3 \%)\end{array}$ & $\begin{array}{l}24(75.0 \%) \\
8(25.0 \%)\end{array}$ & $\begin{array}{l}2(66.7 \%) \\
1(33.3 \%)\end{array}$ \\
\hline $\begin{array}{l}\text { HBsAg } \\
\text { Positive } \\
\text { Negative }\end{array}$ & $\begin{array}{l}16(71.4 \%) \\
7(28.6 \%)\end{array}$ & $\begin{array}{c}43(93.5 \%) \\
3(6.5 \%)\end{array}$ & $\begin{array}{l}3(66.7 \%) \\
1(33.3 \%)\end{array}$ \\
\hline $\begin{array}{c}\text { Anti-HBsAg } \\
\text { Positive } \\
\text { Negative }\end{array}$ & $\begin{array}{l}6(55.5 \%) \\
5(45.5 \%)\end{array}$ & $\begin{array}{c}2(8.0 \%) \\
23(92.0 \%)\end{array}$ & $\begin{array}{l}- \\
-\end{array}$ \\
\hline $\begin{array}{l}\mathrm{HBeAg} \\
\text { Positive } \\
\text { Negative }\end{array}$ & $\begin{array}{l}5(50.0 \%) \\
5(50.0 \%)\end{array}$ & $\begin{array}{c}8(30.8 \%) \\
18(69.2 \%)\end{array}$ & $\begin{array}{c}3(100 \%) \\
-\end{array}$ \\
\hline $\begin{array}{c}\text { Anti-HBeAg } \\
\text { Positive } \\
\text { Negative }\end{array}$ & $\begin{array}{l}3(30.0 \%) \\
7(70.0 \%)\end{array}$ & $\begin{array}{c}18(66.7 \%) \\
9(33.3 \%)\end{array}$ & $\begin{array}{l}1(50.0 \%) \\
1(50.0 \%)\end{array}$ \\
\hline $\begin{array}{c}\text { HBC-Total } \\
\text { Positive } \\
\text { Negative } \\
\end{array}$ & $\begin{array}{l}9(81.8 \%) \\
2(18.2 \%)\end{array}$ & $\begin{array}{c}21(100 \%) \\
-\end{array}$ & $1(100 \%)$ \\
\hline
\end{tabular}


Genotyping of HBV is important to elucidate the differences in diversity of sequences and viral phylogeny ${ }^{(23)}$. Several methods have been used for genotyping of HBV, including sequencing, PCR with probes, RFLP analysis, colorimetric test for detecting point mutations, ligase chain reaction, mass spectrometry and enzyme-linked immunosorbent assay for genotype-specific epitopes ${ }^{(8,11)}$. The main genotyping systems that have been developed are based on the polymerase chain reaction. The system described by Naito et al. ${ }^{(22)}$ uses primers specific to each type of HBV, allowing the identification of genotypes $\mathrm{A}-\mathrm{F}^{(22)}$, but not $\mathrm{G}$ and $\mathrm{H}$. The system described by Liu WC et al., on the other hand, is based on multiplex PCR ${ }^{(18)}$.

The use of real-time PCR provides rapid results. With a qPCR method that allows genotyping, sequencing and analysis of sequences for diagnostics and treatment are not necessary ${ }^{(35)}$. The molecular diagnosis of $\mathrm{HBV}$ can be accomplished with serum, plasma, or even oral fluid samples $^{(27)}$. Standardization and improvement in the quality and quantity of DNA must be performed for each sample. In this context, Portilho et al. observed that laboratories should standardize their own procedures according to the routines of collecting and processing of samples ${ }^{(27)}$. With this objective, in the present study a previous PCR was conducted to increase the quality and quantity of the viral DNA, both for the sequencing reaction and for the standardization of the multiplex qPCR to study HBV genotypes. After the first reaction, a multiplex PCR with the Sybr Green system was performed. The use of Sybr Green must be followed by melting curve analysis to determine the specificity of the amplified fragment. Several studies use this multiplex methodology, due to its lower operating cost when compared to the Taqman system, whose higher costs are related to the need of synthetic fluorescent probes consisting of fluorochrome and quencher, in addition to primers ${ }^{(24)}$.

This is the first study using a multiplex PCR technique for the genotyping of hepatitis B virus in the state of Rio Grande do Sul, Southern Brazil. The use of melting curve analysis showed that the specificity and reproducibility were similar to previously published results for other viruses ${ }^{24,25,31)}$.

Several reports have described the use of qPCR for the identification of strains, however with a generalist approach. Daniel et al. have developed an in house assay for the quantification of HBV, suggesting the use of a multiplex reaction for the identification of co-infections with hepatitis $\mathrm{C}$ virus and human immunodeficiency virus ${ }^{(5)}$. Liu et al. used melting curve analysis as a tool for definition of HBV genotypes; in that study, a pre-PCR step using specific probes separated the genotypes in two groups prior to the $\mathrm{PCR}^{(17,18)}$. In the present study, a set of multiplex primers was used for detection of the most common HBV genotypes in our country, especially in Rio Grande do Sul; therefore, our methodology was faster and did not require specific probes, which usually implies in higher costs.

The set of primers designed in the present study has the advantage to determine the genotype directly in the PCR, without further methodological steps. In addition, the method was designed to have greater accuracy in genotyping and greater sensitivity to identify mixed genotypes when compared to sequencing reactions, which are usually employed in diagnostic laboratories in our region. A recent study by Yin et al. demonstrated the importance of a co-infection of HBV genotypes, resulting in increased viral load as well as increased risk for the development of $\mathrm{HCC}^{(36)}$. A possible limitation of their method is that the genotype is not identified by a single reaction, requiring further analytical steps.

The reasons for the absence of HBV DNA in the serum of HBsAg-positive patients in our study remain unknown. However, the presence of HBV variants with a low level of replication, which in the present study resulted in absence of $\mathrm{HBeAg}$, can and should be considered as inhibitory mechanisms related to the immune system of infected patients or false-positive results of viral antigen. However, it should be pointed out that $\mathrm{HBV}$ and its genotypes could be identified in $\mathrm{HBeAg}$-negative patients with normal aminotransferase levels, suggesting that adjustments in the methodology used could provide better sensitivity even in this population of inactive carriers of HBV. Other parameters related to the detection of HBV DNA should be examined, such as the diagnostic method used, the storage conditions of the samples and the type of biological material analyzed (serum, peripheral blood mononuclear cells and hepatic tissue).

In this study, a high prevalence of genotype D (63\%), followed by genotype A (32\%) was found in patients of Rio Grande do Sul. Genotype F was found in only 5\% of the population investigated. Similar results were reported in Brazil by Haddad and also by a previous study of our group ${ }^{(2,13)}$.

The distribution of genotypes in the Brazilian population correlates with the origin of our ancestors. The frequency of genotypes A and D suggests the influence of African ancestry, resulting from the period of slavery, as well as the influence of European colonization. Studies conducted at Instituto Oswaldo Cruz (IOC), a pioneer in establishing the genotype of viruses in Brazil, showed that about $50 \%$ of the viruses found in the country have the A genotype, which is the African subtype, possibly related to the introduction of Africans in Brazil by the slave trade.

A study in Bahia with 120 patients with chronic hepatitis B showed that the most frequent genotype was A, followed by genotype $\mathrm{F}^{(12,29)}$. In Rio Grande do Sul, there is a predominance of European descendants. In this study, genotype D, which has a global distribution, was the most prevalent in the group of patients with chronic hepatitis B, similar to previous reports $^{(2)}$. The frequencies of HBV genotypes observed in the present study, with prevalence of genotype $\mathrm{D}$, followed by A and $\mathrm{F}$, are similar to a previous investigation conducted in the southern region ${ }^{(28)}$. The $\mathrm{D}$ genotype is found mainly in the Mediterranean region, from where a major wave of immigrants, including Italians, Spaniards and Portuguese, came to southern Brazil ${ }^{(12)}$, which may explain the present findings. The F genotype is characteristic of the native population of the Americas, and has increased frequency in Argentina ${ }^{(33)}$, which explains the frequency found in the present study. We did not observe the genotypes B, C, E, G and H in the patients included in this investigation. 
The time course of detection of serologic markers can be related to immunological windows, regardless of HBV genotype. In this study, an increased frequency of patients with the C-genotype HBV, but not with the A genotype, were negative for anti-HBsAg and $\mathrm{HBeAg}$. These results suggested that these patients were not in the infectious stage. We also observed that 18 patients with C-genotype $\mathrm{HBV}$ were positive for $\mathrm{HBeAg}$, suggesting active phase. Sitinik and collaborators found that pre-core mutations can cause negative results for $\mathrm{HBeAg}$, showing the need for further studies comparing the serology of patients and HBV genotypes ${ }^{(32)}$. Lack of information about the stage of treatment of each patient hampers a more detailed investigation, and may lead to erroneous interpretation of serological patterns. Few studies relate serological markers of hepatitis B with HBV genotypes.

\section{CONCLUSION}

The PCR assay described in this study provides a rapid and accurate method to differentiate HBV genotypes (A, D and F) using a Nested-Multiplex qPCR with specific primers. This method can be useful for HBV genotyping in large clinical scale and epidemiological studies, especially in regions with high prevalence of $\mathrm{HBV}$ infection. The simplicity and speed of this PCR assay can reduce the cost and complexity of genotype identification.

Becker CE, Kretzmann NA, Mattos AA, Veiga ABG. Análise da curva de melting para o screening dos genótipos A, D e F do vírus da hepatite B em pacientes de um hospital geral do sul do Brasil. Arq Gastroenterol. 2013,50(3):219-25.

RESUMO - Contexto - O vírus da hepatite B pode causar hepatite fulminante, cirrose e carcinoma hepatocelular, sendo uma das causas mais frequentes de doença aguda e crônica do fígado. As variantes genéticas do VHB podem ser determinantes para a evolução da doenças assim como para a eleição da terapêutica. Objetivos - O objetivo deste estudo foi padronizar e avaliar uma metodologia "in house", através da utilização da curva de melting de reação em cadeia da polimerase (PCR) em tempo real (qPCR), como rastreamento para análise dos genótipos A, D e F do vírus da hepatite B em pacientes do Rio Grande do Sul. Métodos - Foram avaliados 104 pacientes supostamente com infecção crônica pelo VHB. O DNA foi extraído com kit comercial, os genótipos e as mutações foram determinados utilizando diferentes protolocos baseados em PCR. Resultados - Foi padronizada uma metodologia baseada em PCR para a análise dos genótipos A, D e F do VHB. A técnica consistiu de uma PCR Nested incluindo uma etapa final de PCR em tempo real Multiplex, utilizando a curva de melting como ferramenta para a definição dos fragmentos. Foi observada uma maior frequência do genótipo D (44,4\%), seguido do genótipo A (22,2\%) e do genótipo F (3,7\%) na amostra analisada. Conclusão - O ensaio padronizado fornece um método rápido e preciso para diferenciar genótipos do VHB mais frequentes no sul do Brasil - A, D e F - usando um PCR Nested Multiplex com primers específicos, o qual apresenta potencial aplicação na prática clínica.

DESCRITORES - Vírus da hepatite B. Análise da curva de melting. Genótipos. Reação em cadeia da polimerase em tempo real. Rio Grande do Sul, Brasil. 


\section{REFERENCES}

1. Beasley RP. Rocks along the road to the control of HBV and HCC. Ann Epidemiol. 2009;19:231-4

2. Becker C, Mattos A, Bogo M, Branco F, Sitnik R, Kretzmann N. Genotyping of hepatitis B virus in a cohort of patients evaluated in a hospital of Porto Alegre, South of Brazil. Arq Gastroenterol. 2010;47:13-7.

3. Carman WF. The clinical significance of surface antigen variants of hepatitis $B$ virus. J Viral Hepat. 1997;4 Suppl 1:11-20.

4. Carrilho FJ, Moraes CR, Pinho JR, Mello IM, Bertolini DA, Lemos MF, Moreira RC, Bassit LC, Cardoso RA, Ribeiro-dos-Santos G, Da Silva LC. Hepatitis B virus infection in Haemodialysis Centres from Santa Catarina State, Southern Brazil. Predictive risk factors for infection and molecular epidemiology. BMC Public Health. 2004;4:13.

5. Daniel HD, Fletcher JG, Chandy GM, Abraham P. Quantitation of hepatitis B virus DNA in plasma using a sensitive cost-effective "in-house" real-time PCR assay. Indian J Med Microbiol. 2009;27:111-5.

6. El-Serag HB. Epidemiology of viral hepatitis and hepatocellular carcinoma Gastroenterology. 2012;142:1264-73.e1

7. Elamin S, Abu-Aisha H. Prevention of hepatitis B virus and hepatitis $\mathrm{C}$ virus transmission in hemodialysis centers: review of current international recommendations. Arab J Nephrol Transplant. 2011;4:35-47.

8. Farazmandfar T, Haghshenas MR, Janbabai G, Azadeh H, Sharifian R, Taghipour $M$. A rapid and reliable genotyping method for hepatitis $B$ virus genotypes $(A-H)$ using type-specific primers. J Virol Methods. 2012;181:114-6.

9. Ferreira RC, Teles SA, Dias MA, Tavares VR, Silva SA, Gomes SA, Yoshida $\mathrm{CF}$, Martins RM. Hepatitis B virus infection profile in hemodialysis patients in Central Brazil: prevalence, risk factors, and genotypes. Mem Inst Oswaldo Cruz. 2006;101:689-92

10. Franco E, Bagnato B, Marino MG, Meleleo C, Serino L, Zaratti L. Hepatitis B: Epidemiology and prevention in developing countries. World J Hepatol. 2012;4:74-80.

11. Ganova-Raeva L, Ramachandran S, Honisch C, Forbi JC, Zhai X, Khudyakov Y. Robust hepatitis B virus genotyping by mass spectrometry. J Clin Microbiol. 2010;48:4161-8.

12. Gonçalves CS, Pereira FE, Gayotto LC. Hepatocellular carcinoma in Brazil: report of a national survey (Florianópolis, SC, 1995). Rev Inst Med Trop Sao Paulo. 1997;39:165-70

13. Haddad R, Martinelli AeL, Uyemura SA, Yokosawa J. Hepatitis B virus genotyping among chronic hepatitis B patients with resistance to treatment with lamivudine in the City of Ribeirão Preto, State of São Paulo. Rev Soc Bras Med Trop. 2010;43:224-8.

14. Hui CK, Lau GK. Treatment of Hepatitis B e Antigen-negative Patients. Curr Treat Options Gastroenterol. 2007;10:474-82.

15. Kim BK, Revill PA, Ahn SH. HBV genotypes: relevance to natural history, pathogenesis and treatment of chronic hepatitis B. Antivir Ther. 2011;16:1169-86.

16. Liu CJ, Kao JH, Chen DS. Therapeutic implications of hepatitis B virus genotypes. Liver Int. 2005;25:1097-107.

17. Liu WC, Mizokami M, Buti M, Lindh M, Young KC, Sun KT, Chi YC, Li HH, Chang TT. Simultaneous quantification and genotyping of hepatitis B virus for genotypes A to G by real-time PCR and two-step melting curve analysis. J Clin Microbiol. 2006;44:4491-7.

18. Liu WC, Lindh M, Buti M, Phiet PH, Mizokami M, Li HH, Sun KT, Young KC, Cheng PN, Wu IC, Chang TT. Genotyping of hepatitis B virus--genotypes a to $\mathrm{g}$ by multiplex polymerase chain reaction. Intervirology. 2008;51:247-52.

19. Locarnini S. Molecular virology of hepatitis B virus. Semin Liver Dis. 2004;24 Suppl 1:3-10
20. Locarnini S, Zoulim F. Molecular genetics of HBV infection. Antivir Ther. 2010;15 Suppl 3:3-14.

21. Mackay IM. Real-time PCR in the microbiology laboratory. Clin Microbiol Infect. 2004; 10:190-212

22. Naito H, Hayashi S, Abe K. Rapid and specific genotyping system for hepatitis B virus corresponding to six major genotypes by PCR using type-specific primers. J Clin Microbiol. 2001;39:362-4.

23. Norder H, Hammas B, Lee SD, Bile K, Couroucé AM, Mushahwar IK, Magnius LO. Genetic relatedness of hepatitis B viral strains of diverse geographical origin and natural variations in the primary structure of the surface antigen. J Gen Virol. 1993;74:1341-8.

24. Paudel D, Jarman R, Limkittikul K, Klungthong C, Chamnanchanunt S, Nisalak A, Gibbons R, Chokejindachai W. Comparison of real-time SYBR green dengue assay with real-time taqman RT-PCR dengue assay and the conventional nested PCR for diagnosis of primary and secondary dengue infection. N Am J Med Sci. 2011;3:478-85.

25. Pérez LJ, Díaz de Arce H, Tarradas J, Rosell R, Perera CL, Muñoz M, Frías MT, Nuñez JI, Ganges L. Development and validation of a novel SYBR Green real-time RT-PCR assay for the detection of classical swine fever virus evaluated on different real-time PCR platforms. J Virol Methods. 2011;174:53-9.

26. Perrillo RP. Acute flares in chronic hepatitis B: the natural and unnatural history of an immunologically mediated liver disease. Gastroenterology. 2001;120:1009-22.

27. Portilho MM, Martins PP, Lampe E, Villar LM. A comparison of molecular methods for hepatitis B virus (HBV) DNA detection from oral fluid samples. J Med Microbiol. 2012;61:844-51.

28. Realdi G, Fattovich G, Hadziyannis S, Schalm SW, Almasio P, Sanchez-Tapias J, Christensen E, Giustina G, Noventa F. Survival and prognostic factors in 366 patients with compensated cirrhosis type B: a multicenter study. The Investigators of the European Concerted Action on Viral Hepatitis (EUROHEP). J Hepatol. 1994 Oct;21(4):656-66.

29. Ribeiro NR, Campos GS, Angelo AL, Braga EL, Santana N, Gomes MM, Pinho JR, De Carvalho WA, Lyra LG, Lyra AC. Distribution of hepatitis B virus genotypes among patients with chronic infection. Liver Int. 2006;26:636-42.

30. Sanger F, Coulson AR. A rapid method for determining sequences in DNA by primed synthesis with DNA polymerase. J Mol Biol. 1975;94:441-8.

31. Shahzamani K, Sabahi F, Merat S, Sadeghizadeh M, Lashkarian HE, Rezvan H, Rezvan H, Samiee SM, Arzanani MK, Jabbari H, Malekzadeh R. Rapid low-cost detection of hepatitis C virus RNA in HCV-infected patients by real-time RT-PCR using SYBR Green I. Arch Iran Med. 2011;14:396-400.

32. Sitnik R, Pinho JR, Bertolini DA, Bernardini AP, Da Silva LC, Carrilho FJ. Hepatitis $\mathrm{B}$ virus genotypes and precore and core mutants in Brazilian patients. J Clin Microbiol. 2004;42:2455-60.

33. Telenta PF, Poggio GP, López JL, Gonzalez J, Lemberg A, Campos RH. Increased prevalence of genotype F hepatitis B virus isolates in Buenos Aires, Argentina. J Clin Microbiol. 1997;35:1873-5.

34. Teles SA, Martins RM, Vanderborght B, Stuyver L, Gaspar AM, Yoshida CF. Hepatitis B virus: genotypes and subtypes in Brazilian hemodialysis patients Artif Organs. 1999;23:1074-8.

35. Tichopad A, Bar T, Pecen L, Kitchen R, Kubista M, Pfaffl M. Quality control for quantitative PCR based on amplification compatibility test. Methods. 2010;50 308-12.

36. Yin J, Zhang H, Li C, Gao C, He Y, Zhai Y, Zhang P, Xu L, Tan X, Chen J, Cheng $\mathrm{S}$, Schaefer S, Cao G. Role of hepatitis B virus genotype mixture, subgenotypes C2 and B2 on hepatocellular carcinoma: compared with chronic hepatitis B and asymptomatic carrier state in the same area. Carcinogenesis. 2008;29:1685-91.

Received 8/1/2013. Accepted 18/6/2013. 